\section{Evaluation of Surface Roughness and Bacterial Adhesion on Tooth Enamel Irradiated With High Intensity Lasers}

\author{
Ruchele D. Nogueira ${ }^{1}$, Camilla B. Silva ${ }^{1}$, Cesar P. Lepri², Regina Guenka
} Palma-Dibb³, Vinicius R. Geraldo-Martins²

\begin{abstract}
The aim was to evaluate the surface roughness and bacterial adhesion on enamel irradiated with high intensity lasers, associated or not to a fluoride varnish. Eighty fragments of bovine enamel were equally divided in 8 groups $(n=10)$. Group 1 was not treated and Group 2 received only a 5\% fluoride varnish application. The other groups were irradiated with an Er:Cr:YSGG $\left(8.92 \mathrm{~J} / \mathrm{cm}^{2}\right)$, an Nd:YAG $\left(84.9 \mathrm{~J} / \mathrm{cm}^{2}\right)$ and a diode laser $\left(199.04 \mathrm{~J} / \mathrm{cm}^{2}\right)$, associated or not to a $5 \%$ fluoride varnish. The surface roughness was measured before and after treatments. Afterward, all samples were incubated in a suspension of $S$. mutans at $37{ }^{\circ} \mathrm{C}$ for $24 \mathrm{~h}$. The colony-forming units (CFU) were counted by a stereoscope and the results were expressed in CFU/mm². One-way ANOVA and the Tukey's test compared the roughness data and the Student's test compared the results obtained in the bacterial adhesion test $(\alpha=5 \%)$. The results showed that the irradiated samples without varnish presented the same roughness and the same bacterial adhesion that the non-irradiated samples. However, samples irradiated in the presence of fluoride varnish showed higher surface roughness and higher bacterial adhesion than the non-irradiated samples and those irradiated without varnish. Presence of pigments in the varnish increased the lasers' action on the enamel surface, which produced ablation in this hard tissue and significantly increased its surface roughness. For this reason, the enamel's susceptibility to bacterial adhesion was higher when the irradiation of the samples was made in presence of fluoride varnish.
\end{abstract}

'Biopathology Division, Dental School, UNIUBE - Universidade de Uberaba, Uberaba, MG, Brazil ${ }^{2}$ Clinical Dentistry, Dental School, UNIUBE - Universidade de Uberaba, Uberaba, MG, Brazil ${ }^{3}$ Department of Restorative Dentistry, Ribeirão Preto Dental School, USP - Universidade de São Paulo, Ribeirão Preto, SP, Brazil

Correspondence: Vinicius Rangel Geraldo Martins, Av. Nenê Sabino, 1801, Sala 2D04, 38.055-500 Uberaba, MG, Brasil. Tel:+55-34-3319-8913. e-mail: vinicius.martins@uniube.br

Key Words: laser, enamel, surface roughness, Streptococcus mutans

\section{Introduction}

Irradiation of dental enamel with high power lasers has shown to be effective in preventing dental caries, because they can provide significant reduction in mineral loss by the acid challenges in the oral cavity $(1,2)$. Different hypotheses have been proposed to explain the changes promoted by irradiation in dental enamel resulting in a preventive effect. All theories are related to the temperature increase in the irradiated tissue, which leads to structural and chemical changes in enamel and dentin (3). The main chemical changes in enamel due to photothermal effects are that the prevailing $\mathrm{CO}_{3}$ component in the phosphate position decreases and the acid phosphate ions condense to form pyrophosphate ions. At higher temperatures occurs a thermal re-crystallization and crystal size growth and the pyrophosphate reacts with apatite to form $\mathrm{PO}_{4}$. The hypothesis is that these effects make enamel less soluble to acids (4).

Another hypothesis is that the incomplete decomposition of the enamel organic matrix during irradiation leads to an obstruction of the inter- and intraprismatic spaces. Consequently, acid diffusion through the inner layers of enamel is compromised, which results in a delay of the enamel demineralization. This effect occurs when the enamel surface reaches temperatures near $400{ }^{\circ} \mathrm{C}$ (5).
The decrease in the enamel porosity also occurs due to surface melting, which happens as the tissue is heated to temperatures around $1200{ }^{\circ} \mathrm{C}(6)$. It should be stressed that increase in temperature of the enamel surface during irradiation increases the risk of tissue ablation and removal of hard tissue is not desirable when the aim of the treatment is the prevention of dental caries. Additionally, the used fluences must be safe for ensuring the vitality of the pulp and periodontal tissues. However, some care is required, since even at low energy densities, the temperature at the superficial layers of the dental enamel reaches values above $800{ }^{\circ} \mathrm{C}$ during irradiation (7).

Studies have demonstrated that a combined fluoridelaser treatment makes enamel more resistant to acid than either laser treatment or fluoride treatment alone $(1,3,8-13)$. The reason for that effect is that subablative low-energy laser irradiation and fluoride treatment may instantaneously transform enamel hydroxyapatite into fluoridated hydroxyapatite, reducing enamel solubility and preventing enamel demineralization (3). Additionally, laser irradiated enamel may retain fluoride ions longer than non-irradiated enamel, increasing its resistance to demineralization over time (14).

Scanning electron microscopy analysis revealed 
significant morphological alterations of the $\mathrm{Nd}: Y A G$ diode (808 and $980 \mathrm{~nm}$ ) and $\mathrm{Er}, \mathrm{Cr}: Y S G G$ laser-irradiated enamel surface, like melting and recrystallization, cracks and porosities $(12,15,16)$. However, it is unclear whether those effects alter significantly the roughness of the dental enamel. An increase in tissue roughness could lead to a greater bacterial adhesion on the irradiated surface, greater accumulation of biofilm and leave the enamel more susceptible to external staining.

The objective of the present study was to evaluate the surface roughness and the bacterial adhesion on dental enamel irradiated with high intensity lasers, associated or not to a $5 \%$ sodium fluoride varnish. The null hypothesis was that the enamel roughness, as well as the bacterial adhesion, are unchanged after laser irradiation, with or without fluoride over the enamel surface.

\section{Material and Methods}

\section{Sample Preparation}

Eighty freshly extracted bovine incisors were stored in a $0.1 \%$ thymol solution ( $\mathrm{pH} 7.0$ ) for up to one month. The crowns were separated from the roots using a water-cooled diamond disc (Isomet; Buehler Ltd., Lake Bluff, IL, USA) mounted in a sectioning machine (Minitom; Struers Inc., Westlake, $\mathrm{OH}, \mathrm{USA})$. The crowns were sectioned to obtain 80 enamel blocks $(5 \times 5 \times 3 \mathrm{~mm})$. Each enamel fragment was coated with a waterproof varnish (Colorama Maybelline, São Paulo, SP, Brazil), excluding a $9,0 \mathrm{~mm}^{2}$ area on the buccal surface of the fragment, where the treatments occurred. Prior to the experiment, the specimens were cleaned and stored in distilled water.

\section{Surface Roughness Baseline}

Before the experiments, the surface roughness $(\mathrm{Sa}, \mu \mathrm{m})$ of each enamel sample was assessed by a 3D Laser Confocal Microscope (LEXT 4000; Olympus, Hamburg, Germany) at a magnification of $40 x$. All data were obtained at a $1024 \times 1024$ pixels resolution.

\section{Experimental Groups}

The samples were cleaned with pumice and water, using a rubber cup at low speed, and divided into eight groups $(n=10)$ and treated as follows (Table 1$)$ :

Group 1 (G1) had no treatment (control). The samples of Group 2 (G2) were actively dried with air and had an application of $9,0 \mathrm{mg} 5 \%$ sodium fluoride varnish (NaF; Duraphat, Colgate-Palmolive Ind. e Com. Ltda, São Paulo, $\mathrm{SP}$, Brazil) for $10 \mathrm{~s}$. After $2 \mathrm{~min}$, the samples were placed in distilled water at $37^{\circ} \mathrm{C}$.

The samples of Group 3 (G3) were actively dried with air and irradiated with an $\mathrm{Er}, \mathrm{Cr}: Y S G G$ laser device (Waterlase ${ }^{\mathrm{TM}}$; Biolase Technology Inc., San Clemente, CA, USA). This equipment emits pulses at a $2.78 \mu \mathrm{m}$ wavelength and was used to irradiate the exposed surface in a non-contact mode (perpendicular to the enamel surface), scanning it for $20 \mathrm{~s}$ under the following parameters: $0.5 \mathrm{~W}, 8.92 \mathrm{~J} /$ $\mathrm{cm}^{2}, 20 \mathrm{~Hz}$ repetition rate, with a sapphire fiber $(600 \mu \mathrm{m}$ spot size). After irradiation, the samples were placed in distilled water at $37^{\circ} \mathrm{C}$.

The samples of Group 4 (G4) were actively dried with air, coated with $9.0 \mathrm{mg}$ fluoride varnish (Duraphat, Colgate) and irradiated with the same Er,Cr:YSGG laser device with the previously described parameters. After irradiation, the samples were placed in distilled water at $37^{\circ} \mathrm{C}$.

The samples of Group 5 (G5) were actively dried with air and irradiated with a Nd:YAG laser (SmartFile; DEKA Laser Technologies, Inc., Carlsbad, CA, USA). This equipment emits pulses at a $1.064 \mu \mathrm{m}$ wavelength and was used to irradiate the exposed surface in a contact mode (perpendicular to the enamel surface), scanning it for $20 \mathrm{~s}$ under the following parameters: $84.9 \mathrm{~J} / \mathrm{cm}^{2}, 0.6 \mathrm{~W}, 10 \mathrm{~Hz}$ repetition rate, with a quartz fiber optic (300 $\mu \mathrm{m}$ spot size). After irradiation, the samples were stored in distilled water at $37^{\circ} \mathrm{C}$.

The samples of Group 6 (G6) were actively dried with air, coated with $9.0 \mathrm{mg}$ fluoride varnish (Duraphat, Colgate) and irradiated with the same Nd:YAG laser device and the previously described parameters. After irradiation, the samples were stored in distilled water at $37^{\circ} \mathrm{C}$.

The samples of Group 7 (G7) were actively dried with air and irradiated with a diode laser device (DClase Soft Tissue Diode Laser; DC International LLC, Wellington, FL, USA). This equipment emits pulses at a $980 \mathrm{~nm}$ wavelength and was used to irradiate the exposed surface in a non-contact mode (perpendicular to the enamel surface), scanning it for $20 \mathrm{~s}$ under the following parameters: $5.0 \mathrm{~W}, 199.04 \mathrm{~J} /$ $\mathrm{cm}^{2}, 20 \mathrm{~Hz}$ repetition rate, with a sapphire fiber $(400 \mu \mathrm{m}$ spot size). After irradiation, the samples were stored in

Table 1. Experimental groups

\begin{tabular}{lccc}
\hline Group (n-10) & Laser & $\begin{array}{c}\text { 5\% Fluoride } \\
\text { varnish }\end{array}$ & $\begin{array}{c}\text { Power } \\
\text { output }(\mathrm{W})\end{array}$ \\
\hline 1 (Control) & ------- & ------- & 0 \\
$2(5 \% \mathrm{NaF})$ & ------ & Yes & 0 \\
3 (Er,Cr:YSGG) & Er,Cr:YSGG & No & 0.5 \\
4 (Er,Cr:YSGG & Er,Cr:YSGG & Yes & 0.5 \\
$+5 \% \mathrm{NaF})$ & Nd:YAG & No & 0.6 \\
5 (Nd:YAG) & Nd:YAG & Yes & 0.6 \\
6 (Nd:YAG + & Diode & No & 5.0 \\
$7 \% \mathrm{NaF})$ & Diode & Yes & 5.0 \\
8 (Diode) & & & \\
$5 \% \mathrm{NaF})$ & &
\end{tabular}


distilled water at $37^{\circ} \mathrm{C}$.

The samples of Group 8 (G8) were actively dried with air, coated with $9.0 \mathrm{mg}$ fluoride varnish (Duraphat, Colgate) and irradiated with the same diode laser device and the previously described parameters. After irradiation, the samples were stored in distilled water at $37^{\circ} \mathrm{C}$.

All laser parameters used here were previously described as effective to increase the acid resistance of the enamel surface $(1,8-10,12)$.

\section{Analysis of Surface Roughness}

Quantitative changes on the enamel surface roughness $(\mathrm{Sa}, \mu \mathrm{m})$ were assessed by a 3D Laser Confocal Microscope (LEXT 4000; Olympus Co., Hamburg, Germany) at a 40x magnification. All data were documented at a $1024 \times 1024$ pixels resolution.

\section{Bacterial Adhesion Test}

First, the enamel samples were individually placed into 24-well cell culture plates filled with deionized water and irradiated in a microwave (650 $\mathrm{W}$ for $3 \mathrm{~min}$ ). This method is effective for a complete disinfection of bovine enamel specimens without affecting the structure of the dental hard tissue (17). For the bacterial adhesion test, Streptococcus mutans (ATCC 25175) grown repeatedly in sucrose medium was used. The enamel samples in the sterile cell culture plates were coated with $1.5 \mathrm{~mL}$ of Brain Heart Infusion broth supplemented with 5\% sucrose (BHI-S; Difco, Sparks, MD, USA), inoculated overnight with standardized cultures $\left(\cong 8.8 \times 10^{7}\right.$ colony-forming units $\left.[\mathrm{CFU}] / \mathrm{mL}\right)$ in the same medium and incubated for $24 \mathrm{~h}$ at $37^{\circ} \mathrm{C}$. All incubations followed the previously described protocol (18).

After incubation, the enamel fragments were removed

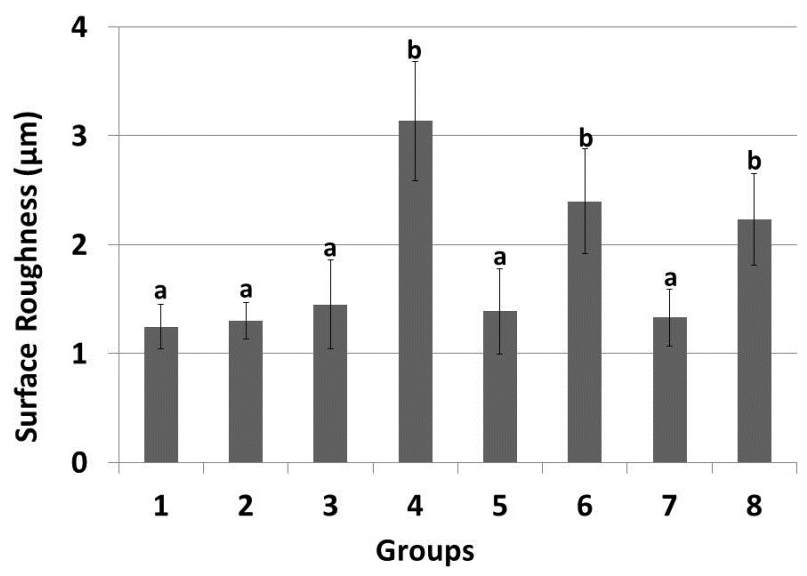

Figure 1. Mean ( \pm standard deviation) of surface roughness (Sa) found in all experimental groups. Different letters indicate the presence of a difference that was statistically significant. $(\mathrm{p}<0.05)$; Groups: 1 (Control), 2 (5\% NaF), 3 (Er,Cr:YSGG), 4 (Er,Cr:YSGG +5\% NaF), 5 (Nd:YAG), 6 (Nd:YAG + 5\% NaF), 7 (Diode), 8 (Diode + 5\% NaF). from the wells with sterile tweezers, and washed in sterile distilled water to remove non-adhering microorganisms. After washing, the samples were placed in tubes containing sterile distilled water and sonicated for $3 \mathrm{~min}$. Subsequently, swab samples from the enamel surface were spread across the surface of the blood agar plates supplemented with sucrose. After $24 \mathrm{~h}$ of incubation at $37^{\circ} \mathrm{C}$, the colonyforming units were counted using a stereoscope and the results were expressed in $\mathrm{CFU} / \mathrm{mm}^{2}$ (19).

\section{Statistical Analysis}

The average of variation in surface roughness was obtained for each group. The surface roughness results were submitted to the Kolmogorov-Smirnov test to verify the normal distribution of the variables. One-way ANOVA and the Tukey's test were performed to compare the averages. The data obtained in the bacterial adhesion test were submitted to the D'Agostino's and to the Student's tests. Pearson's correlation test was performed to evaluate the relationship between the surface roughness and bacterial adhesion. The level of significance adopted in all cases was $5 \%$. All statistical analyses were performed using SPSS version 9.0 (SPSS Inc., Chicago, IL, USA).

\section{Results}

Figure 1 shows the comparison of average surface roughness obtained in all experimental groups. The results revealed that the samples irradiated in the presence of fluoride varnish (G4, G6 and G8) showed higher surface roughness than the non-irradiated samples ( $\mathrm{G} 1$ and $\mathrm{G} 2$ ) and those irradiated without varnish (G3, G5 and G7) $(p<0.05)$. The data found for samples irradiated without varnish and for non-irradiated samples were statistically similar ( $p>0.05$ ). No statistical differences were found among groups treated in the presence of varnish $(p>0.05)$.

Table 2 shows the average $\mathrm{CFU} / \mathrm{mm}^{2}$ obtained in all

Table 2. Average ( \pm standard deviation) of CFU/mm2 (log) obtained in all experimental groups. Different letters indicate a difference that was statistically significant. $(p<0.05)$

\begin{tabular}{lc}
\hline Group & $\mathrm{CFU} / \mathrm{mm}^{2}(\mathrm{log})$ \\
\hline 1 (Control) & $8.15(0.73) \mathrm{a}$ \\
$2(5 \% \mathrm{NaF})$ & $9.2(0.82) \mathrm{a}$ \\
3 (Er,Cr:YSGG) & $11.4(1.16) \mathrm{a}$ \\
4 (Er,Cr:YSGG +5\% NaF) & $26.4(0.95) \mathrm{b}$ \\
5 (Nd:YAG) & $10.1(0.93) \mathrm{a}$ \\
6 (Nd:YAG + 5\%NaF) & $24.2(1.03) \mathrm{b}$ \\
7 (Diode) & $9.7(0.89) \mathrm{a}$ \\
8 (Diode $+5 \% \mathrm{NaF})$ & $25.7(0.97) \mathrm{b}$ \\
\hline
\end{tabular}


experimental groups. The samples irradiated by all lasers in the presence of fluoride varnish presented higher bacterial adhesion than the control group (G1), the fluoride varnish (G2) and those groups where the irradiation was applied in absence of the fluoride compound $(p<0.05)$. There were no statistical differences among groups treated with laser and varnish.

To verify whether the surface roughness had an influence on the bacterial adhesion to enamel surface, was used the Pearson's correlation test. There was a high positive correlation between surface roughness and bacterial adhesion ( $r=0.94 ; p=0.0005)$.

\section{Discussion}

The null hypothesis that the enamel roughness would not change after laser irradiation with or without fluoride over the enamel surface, was rejected, since the irradiation without $5 \% \mathrm{NaF}$ presence did not change the surface roughness of bovine enamel. The bacterial adhesion was also higher on the enamel surface irradiated in presence of $5 \% \mathrm{NaF}$ varnish.

Dental caries is a chronic disease caused by several factors, including the accumulation of a cariogenic biofilm on the tooth enamel. The bacteria in that biofilm produce acids that reduce $\mathrm{pH}$ on the enamel surface. If this biofilm is not removed from the dental tissue, the enamel is demineralized, and in more severe cases, a cavity forms in the hard dental tissue (20). The biofilm formation and bacterial adhesion is better formed and accumulated on rougher surfaces, because these areas are more difficult to clean by the action of saliva or by tooth brushing. Thus, a smoother surface or with few irregularities is less susceptible to caries lesions (20).

As described before, high intensity lasers have been used to inhibit enamel demineralization by increasing the surface temperature of the irradiated tissue, which reduces the hydroxyapatite solubility and blocks the interprismatic spaces due to the melting and recrystallization of the surface. Additionally, the use of a fluoride varnish or gel before irradiation may convert enamel hydroxyapatite into fluoridated hydroxyapatite, reducing enamel solubility and allowing the irradiated surface to retain fluoride ions longer than non-irradiated enamel $(3,14)$.

The thermal effects are based on the strong absorption of erbium lasers radiation by water and hydroxyapatite from enamel. Higher absorption of laser energy on the enamel surface may lead to changes in the crystallographic structure of enamel and it depends on the applied energy density, which is directly proportional to the increase in temperature generated on the tissue surface (21). A previous study revealed that irradiation of enamel with $\mathrm{Er}, \mathrm{Cr}: \mathrm{YSGG}$ laser using low energy densities $\left(8.5 \mathrm{~J} / \mathrm{cm}^{2}\right)$ were able to produce slight cavities, typical of microablation areas with fissures and conical craters, with sharp enamel projections (12). However, according to the results obtained in this study, the changes produced by $\mathrm{Er}, \mathrm{Cr}: Y S G G\left(8.92 \mathrm{~J} / \mathrm{cm}^{2}\right)$ on enamel were not able to change the surface roughness of this hard tissue. However, the surface irradiated in the presence of fluoride varnish became rougher. The hypothesis is that this result was due to the $5 \%$ fluoride varnish composition used in the present study, which has a yellow-brownish color. According to the manufacturer, the varnish is composed by sodium fluoride (5\%), ethanol, white bee wax (E901), gum lac (E904), colophane, mastic, saccharine (E954) and raspberry essence. Thus, the hydroxyl groups in the ethanol and other components of the varnish absorbed radiation and facilitated ablation of the irradiated surface, and therefore increased the enamel roughness.

A similar explanation may be used to describe the results obtained when the Nd:YAG laser was used. The Nd:YAG laser emits near-infrared wavelengths $(1,064 \mathrm{~nm})$ and, therefore it is not effectively absorbed by dental enamel (absorption coefficient is less than $4 \times 10^{-2} \mathrm{~cm}^{-1}$ ) (8). This explains the fact that this laser did not significantly change the enamel roughness, when compared to the non-irradiated samples. However, Nd:YAG is strongly absorbed by hemoglobin, melanin and dark pigments (8). In this way, to increase the absorption of the laser beam on the surface of the enamel, use of photoabsorbers before Nd:YAG laser irradiation on dental hard tissues has been reported $(8,9)$. In this situation, the heat generated due to laser absorption by the cover material pervades into the adjacent enamel. This method ensures the action of a short laser pulse energy on a small volume of tissue, hindering excessive penetration of the laser beam into deeper dental structures, and consequently, decreasing the risk of damage to the dental pulp $(8,9)$.

As described before, the fluoride varnish used here has a yellow-brownish color. Thus, it is believed that the presence of these pigments has increased the absorption of the Nd:YAG laser on the enamel surface, which produced ablation in the irradiated tissue, and significantly increased the surface roughness.

The same explanation for $\mathrm{Nd}: Y A G$ laser can explain the results obtained with the diode laser. The diode laser used in this study emits photons at a wavelength of $980 \mathrm{~nm}$ and, therefore, it is not well absorbed by tooth enamel (22). For that reason, some authors choose to irradiate enamel with a pigmented varnish over the tissue surface $(22,23)$. As described above, this method enhances the absorption of the laser beam on the tissue surface, changing its chemical and morphological structure, and increasing its acid resistance $(10,11,22,23)$. Previous studies revealed that diode laser increases fluoride uptake when enamel is irradiated in the presence of a fluoride compound, and they also 
stated that enamel must be irradiated in the presence of a pigmented coating substance to increase the acid resistance of enamel $(10,11)$. According to this, the pigmented $5 \%$ $\mathrm{NaF}$ varnish used here acted as a photo-absorber for the diode laser photons, generating photothermal effects in enamel and changing the morphology of the enamel and, therefore, its roughness.

The results obtained showed that bacterial adhesion was higher in samples irradiated in the presence of fluoride varnish, regardless of the used laser. This suggests that the increase in enamel surface roughness was responsible of the bacterial adherence increase in G4, G6 and G8. In fact, the statistical analysis showed a high positive correlation between surface roughness and bacterial adhesion. In contrast, the bacterial adhesion on the samples irradiated without $\mathrm{NaF}$ varnish was similar to the one found in non-irradiated enamel. Surface roughness is one of the properties of tooth and restorative materials that influence the formation and accumulation of biofilm. On the rough and irregular surfaces the dental biofilm is formed in greater amounts and has quicker maturation when to flat surfaces (24). Past studies indicated that even a demineralized enamel surface, which presents a higher surface roughness $\Xi$ than sound enamel, is able to retain a larger amount of biofilm when compared to the intact enamel $(20,25)$.

In accordance to what was described herein and irrespective of the used wavelength, it may be observed that irradiation of the samples after application of 5\% sodium fluoride varnish produced an increase in the surface roughness of bovine enamel, which consequently resulted in an increase of $S$. mutans adhesion over the dental hard tissue.

Under the conditions of the present study, it may be concluded that the surface roughness of enamel is altered when the irradiation of the samples is made in the presence of 5\% fluoride varnish. The presence of pigments in the varnish increased the action of lasers on the enamel surface, which promoted ablation in that hard tissue and significantly increased its surface roughness. For this reason, the susceptibility to bacterial adhesion of the enamel was higher when the irradiation of the samples was in the presence of fluoride varnish.

\section{Resumo}

0 objetivo foi avaliar a rugosidade superficial e adesão bacteriana no esmalte dental irradiado com lasers de alta intensidade, associados ou não a um verniz fluoretado. Oitenta fragmentos de esmalte foram igualmente divididos em 8 grupos $(n=10)$. 0 grupo 1 não recebeu tratamento e o grupo 2 recebeu aplicação de verniz fluoretado a $5 \%$. Os outros grupos foram irradiados com os lasers Er,Cr:YSGG $\left(8,92 \mathrm{~J} / \mathrm{cm}^{2}\right), \mathrm{Nd}: Y A G\left(84,9 \mathrm{~J} / \mathrm{cm}^{2}\right)$ e um laser de diodo $\left(199,04 \mathrm{~J} / \mathrm{cm}^{2}\right)$, associados ou não ao verniz fluoretado. A rugosidade superficial foi medida antes e após os tratamentos. Depois, todas as amostras foram imersas em suspensão de S. mutans a $37{ }^{\circ} \mathrm{C}$ durante $24 \mathrm{~h}$. As unidades formadoras de colônia (UFC) foram contadas utilizando uma lupa estereoscópica, e os resultados foram expressos em $\mathrm{UFC} / \mathrm{mm}^{2}$. Os resultados de rugosidade foram analisados por ANOVA e pelo teste de Tukey, e a adesão bacteriana foi analisada pelo teste de Student $(\alpha=5 \%)$. As amostras irradiadas sem verniz apresentaram a mesma rugosidade superficial e a mesma adesão bacteriana que as amostras não irradiadas. No entanto, as amostras irradiadas na presença do verniz fluoretado apresentaram maior rugosidade superficial e aderência bacteriana do que as amostras não irradiadas e daquelas irradiadas sem o verniz. A presença de pigmentos no verniz aumentou a ação dos lasers na superfície do esmalte, promovendo a ablação do tecido duro e aumentando significativamente a sua rugosidade superficial. Por isso, a adesão bacteriana no esmalte foi maior quando a irradiação foi realizada na presença do verniz fluoretado.

\section{Acknowledgements}

The authors would like to thank the financial support provided by CAPES (Coordenação de Aperfeiçoamento de Pessoal de Nivel Superior - Grant\# 9996-14-1).

\section{References}

1. Geraldo-Martins VR, Lepri CP, Palma-Dibb RG. Influence of $\mathrm{Er}, \mathrm{Cr}$ :YSGG laser irradiation on enamel caries prevention. Lasers Med Sci 2013;28:33-39.

2. Azevedo DT1, Faraoni-Romano JJ, Derceli JR, Palma-Dibb RG. Effect of $\mathrm{Nd}$ :YAG laser combined with fluoride on the prevention of primary tooth enamel demineralization. Braz Dent J 2012;23:104-109.

3. Liu Y, Hsu CY, Teo CM, Teoh SH. Potential mechanism for the laserfluoride effect on enamel demineralization. J Dent Res 2013;92:71-75.

4. Steiner-Oliveira C, Rodrigues LK, Soares LE, Martin AA, Zezell DM, Nobre-dos-Santos M. Chemical, morphological and thermal effects of 10.6-microm $\mathrm{CO}_{2}$ laser on the inhibition of enamel demineralization. Dent Mater J 2006;25:455-462.

5. Ying D, Chuah GK, Hsu CY. Effect of Er:YAG laser and organic matrix on porosity changes in human enamel. J Dent 2004;32:41-46.

6. Seka W, Fried D, Featherstone JD, Borzillary SF. Light deposition in dental hard tissue and simulated thermal response. J Dent Res 1995;74:1086-1092.

7. Perhavec T, Diaci J. Comparison of heat deposition of Er: YAG and Er,Cr:YSGG lasers in hard dental tissues. J Laser Health Acad 2009;2:16.

8. Boari, HGD, Ana PA, Eduardo CP, Powell GL, Zezell DM. Absorption and thermal study of dental enamel when irradiated with $\mathrm{Nd}$ :YAG laser with the aim of caries prevention. Laser Phys 2009;19:1463-1469.

9. Zezell DM, Boari HG, Ana PA, Eduardo C de P, Powell GL. Nd:YAG laser in caries prevention: a clinical trial. Lasers Surg Med 2009;41:31-35.

10. González-Rodríguez A, de Dios López-González J, del Castillo J de D, Villalba-Moreno J. Comparison of effects of diode laser and $\mathrm{CO} 2$ laser on human teeth and their usefulness in topical fluoridation. Lasers Med Sci 2011;26:317-324.

11. Vitale MC, Zaffe D, Botticell AR, Caprioglio C. Diode laser irradiation and fluoride uptake in human teeth. Eur Arch Paediatr Dent 2011;12:90-92

12. Ana PA, Tabchoury CP, Cury JA, Zezell DM . Effect of Er,Cr:YSGG laser and professional fluoride application on enamel demineralization and on fluoride retention. Caries Res 2012;46:441-451.

13. Mathew A, Reddy NV, Sugumaran DK, Peter J, Shameer M, Dauravu LM. Acquired acid resistance of human enamel treated with laser (Er:YAG laser and $\mathrm{CO}_{2}$ laser) and acidulated phosphate fluoride treatment: An in vitro atomic emission spectrometry analysis. Contemp Clin Dent 2013;4:170-175.

14. Nammour S, Rocca JP, Pireaux JJ, Powell GL, Morciaux Y, Demortier G. Increase of enamel fluoride retention by low fluence argon laser beam: a 6-month follow-up study in vivo. Lasers Surg Med 2005;36:220-224.

15. Banda NR, Vanaja Reddy G, Shashikiran ND. Evaluation of primary tooth enamel surface morphology and microhardness after Nd:YAG laser irradiation and APF gel treatment-an in vitro study. J Clin Pediatr 
Dent 2011:35:377-382

16. Souza MR, Watanabe I, Azevedo LH, Tanji EY. Morphological alterations of the surfaces of enamel and dentin of deciduous teeth irradiated with $\mathrm{Nd}: Y A G, \mathrm{CO}_{2}$ and diode lasers. Int J Morphol 2009;27:441-446.

17. Viana PS, Machado AL, Giampaolo ET, Pavarina AC, Vergani CE. Disinfection of bovine enamel by microwave irradiation: effect on the surface microhardness and demineralization/remineralization processes. Caries Res 2010;44:349-357.

18. Geraldo-Martins V, Thome $T$, Mayer M, Marques M. The use of bur and laser for root caries treatment: a comparative study. Oper Dent 2013;38:290-298.

19. Schweikl H, Hiller KA, Carl U, Schweiger R, Eidt A, Ruhl S, et al.. Salivary protein adsorption and Streptococcus gordonii adhesion to dental material surfaces. Dent Mater 2013;29:1080-1089.

20. Takahashi N, Nyvad B. Caries ecology revisited: microbial dynamics and the caries process. Caries Res 2008;42:409-418.

21. Geraldo-Martins VR, Tanji EY, Wetter NU, Nogueira RD, Eduardo CP. Intrapulpal temperature during preparation with the Er:YAG laser: an in vitro study. Photomed Laser Surg 2005;23:182-186.

22. Sant'Anna GR, Paleari GS, Duarte DA, Brugnera A Jr, Soares CP. Surface morphology of sound deciduous tooth enamel after application of a photo-absorbing cream and infrared low-level laser irradiation: an in vitro scanning electron microscopy study. Photomed Laser Surg 2007;25:500-507.

23. de Sant'Anna GR, dos Santos EA, Soares $L E$, do Espírito Santo $A M$, Martin AA, Duarte DA, et al.. Dental enamel irradiated with infrared diode laser and photo-absorbing cream: part 2 - EDX study. Photomed Laser Surg 2009;27:771-782.

24. Neves PBA, Agnelli JAM, Kurachi C, Souza CWO. Addition of silver nanoparticles to composite resin: effect on physical and bactericidal properties in vitro. Braz Dent J 2014;25:141-145.

25. Arslan S, Zorba YO, Atalay MA, Özcan S, Demirbuga S, Pala K, Percin $D$, Ozer F. Effect of resin infiltration on enamel surface properties and Streptococcus mutans adhesion to artificial enamel lesions. Dent Mater J 2015;34:25-30.
Received July 12, 2016 Accepted November 1, 2016 